\title{
Indicators of Security of Natural Gas Supply in Asia
}

\author{
Helen Cabalu $^{* *}$
}

\section{Introduction}

The growing demand for gas, supply interruptions, increasing gas prices, transportation and distribution bottlenecks, and a growing reliance on imports over longer distances have rekindled a debate on gas security of supply. Natural gas has become an increasingly valuable resource. Its consumption is expected to increase into the future because of its low environmental impact, ease of use and an increase in the number of natural gas-fired power plants. It is one of the fuels that drive the economy. The demand for it, as a replacement for more expensive, less environmentally-friendly and less efficient resources, has already significantly increased (Cabalu and Manhutu, 2009).

The world is dependent on natural gas for power generation. In 2008, it fulfilled more than 24 per cent of the total global primary energy demand (BP, 2009). OECD countries accounted for 50 per cent of gas use, transition economies, especially Russia, used about 20 per cent with developing countries accounting for the rest. Natural gas is forecast to be the fastest growing energy source by 2025, with global consumption rising by almost 60 per cent from 99 trillion cubic feet to 156 trillion cubic feet. The emerging markets of Asia will be the centre of this growth where gas consumption is projected to triple by 2025 (EIA, 2005).

\footnotetext{
** School of Economics and Finance, Curtin Business School, Curtin University of Technology, GPO Box U1987, Perth, Western Australia 6845,E-mail: h.cabalu@curtin.edu.au
} 
The imbalances between supply and demand drive international trade in natural gas. On the one hand are northeast Asian countries (i.e. Japan, Korea, Taiwan and China), which hold just over 1 per cent of world's reserves but account for almost 8 per cent of the demand. On the other hand, the Middle East (particularly Iran and Qatar) and Russia have two-thirds of the world's reserves and account for around 25 per cent of the demand in 2008 (BP, 2009).

Natural gas is also becoming an increasingly global commodity. In the past, gas has tended to be used in the region where it is produced because of the relatively high transport costs. However, technical developments have led to a drastic reduction in gas liquefaction and transport costs making liquefied natural gas (LNG) competitive with traditional pipeline gas. The rapid growth in LNG use and its greater flexibility has started to create a global market for gas. In 2008, approximately 27 per cent of the global natural gas supply was internationally traded with LNG shipments showing strong growth, well above the ten-year average and making up more than 28 per cent of total export volume (BP, 2009). The remaining share of gas sold on the world energy market is distributed via gas pipelines.

In 2008, about 11 per cent of the Asia-Pacific primary energy consumption was based on natural gas. Gas market requirements are mostly met through imports, 90 per cent of which is LNG from Malaysia, Brunei, Indonesia, Australia and the Middle East. Japan and Korea are almost entirely dependent on LNG imports for their gas supplies. In Japan and Korea, imported gas exchanges are based on long term contracts of 20 to 25 years 
and indexation clauses where the gas price is directly linked to the price of crude oil, including relatively strict clauses such as take-or-pay clauses which require importers to pay for the gas even if their deliveries are interrupted. In Australia and New Zealand, prices are set by gas-on-gas or gas-on-coal competition (IAEE, 2007; IEA, 2007; BP 2009).

Short-term security of gas supply is the availability of gas supply despite exceptional demand and difficult supply conditions including disruptions to supply due to physical or economic factors. Physical disruptions can occur when gas supply is exhausted or gas production is stopped. Economic disruptions can be caused by dramatic gas price fluctuations which in turn, are due to physical disruptions or unanticipated price changes associated with speculative reaction to potential disruption.

Long-term security of gas supply on the other hand, is the ability to ensure that future gas demand can be met by a combination of domestic and imported gas supplies. Disruptions to long term security of supply are caused by inadequate investments in production and transmission infrastructure, lack of supply diversity and risks associated with import dependency which are geopolitical in nature. Gas-importing countries have started to examine available responses to disruptions to ensure security of gas supply (Dolader, 2003; Costantini, et al., 2007).

The objective of this paper is to evaluate a set of gas supply security indicators including gas intensity, net gas import dependency, ratio of domestic gas production to total 
domestic gas consumption and geopolitical risk for seven gas-importing countries in Asia for the year 2008. It proposes a composite gas supply security index (GSSI) that is derived as the root mean square of the scaled values of four security of gas supply indicators (Gnansounou, 2008). The four security of gas supply indicators are interrelated and that the GSSI derived provides a composite quantitative measure of gas security by taking into account the interactions and interdependence between the identified set of indicators. The GSSI captures the sensitivity of the Asian economies to developments in the international gas market, with a higher index indicating higher gas supply insecurity or vulnerability. The existing literature does not identify a unique methodology to assess and quantify energy security that is factual, objective, unbiased, transparent and accessible. This paper, however, is important in terms of providing metrics by evaluating a set of parameters and indicators to assess overall natural gas supply security in seven Asian economies. It is important for future policy making to benchmark countries against quantified indicators and assess their gas security of supply weakness.

The seven net gas-importing countries included in this study are Japan, Korea, Taiwan, China, India, Singapore and Thailand, which together account for more than 75 per cent of the total gas consumption in the Asia-Pacific in 2008 (BP, 2009). The paper proceeds as follows. Section 2 reviews related literature on energy supply security, particularly focused on identifying the various indicators used in the literature to indicate energy vulnerability. Section 3 proposes and derives a composite gas supply security index and Section 4 evalua4tes this index for the seven countries in our sample and presents our results and analysis. The final section concludes. 


\section{Review of existing literature on energy security and its indicators}

To date, the literature on assessing energy security has concentrated on oil and mostly on industrialised countries. A number of studies have tried to develop a set of energy supply security indicators to account for both short- and long-term disruptions. Although a number of indicators have been proposed in the literature, there is no consensus on a set of relevant indicators. As a result, time series data to directly assess trends in energy supply security are not readily available and policymakers have therefore relied on a number of parameters associated with energy security to inform decision making.

Jansen, et. al. (2004) studied the energy supply security issue in the European Union by constructing four long-term energy security indicators based on the Shannon diversity index applied to eight primary energy supply sources (coal, oil, gas, modern and traditional biofuels, nuclear, renewables and hydropower). The indicators accounted for supply security aspects such as diversification of energy sources in energy supply, diversification of imports with respect to imported energy sources, political stability in import sources, and the resource base in import sources.

Similarly, Costantini, et. al. (2007) grouped indicators of supply security into two categories: dependence and vulnerability represented in physical and economic terms. The distinction between dependence and vulnerability was made and in their study, the physical dimension of dependence was represented with indicators such as percentage share of net import of oil and gas in total primary energy supply and share of European 
oil and gas imports in world oil and gas imports while the physical dimension of vulnerability was calculated in terms of degree of supply concentration in trade and production using the Shannon-Weiner diversity index, percentage share of oil used in transportation, and percentage share of electricity produced with gas. In terms of the economic dimension of dependence and vulnerability, the value of oil and gas imports and oil and gas consumption per dollar of GDP respectively, were estimated. These indicators of the European energy system were analysed under different energy scenarios.

In a study by de Jong, et. al. (2007), a model was developed for reviewing and assessing energy supply security in the European Union, on the basis of pre-agreed criteria. It used two quantitative indicators and some qualitative considerations. The first quantitative indicator, the Crisis Capability (CC) Index dealt with the risk of sudden unforseen shortterm supply interruptions and the capability to manage them. The second indicator, the Supply/Demand (S/D) Index covered present and future energy supply and demand balances. Qualitative considerations included multilateral measures for securing overall producer/consumer relations and safeguarding vulnerable transport routes for oil and gas.

A number of studies have focused on assessing energy vulnerability. Kendell (1998) explored the meaning and value of measures of import vulnerability as indicators of energy security, in particular, oil security in the United States. While measures of oil import dependence showing the extent of a country's imports may be of interest, they offer a limited indication of energy security. Gupta (2008), APERC (2007), UNDP (2007) have also examined the relative oil vulnerability of oil-importing countries on the 
basis of various factors. Using principal component technique, individual indicators such as domestic oil reserves relative to total oil consumption, geopolitical oil risk, oil intensity, cost of oil in national income and ratio of oil consumption in total primary energy consumption were combined into a composite index of oil vulnerability. Percebois (2007) clarified the distinction between vulnerability and energy dependence and presented a coherent set of indicators including import concentration, level of energy import value in output, risk of blackout in the electricity sector, price volatility, exchange rates, and industrial and technological factors that are used to analyse energy vulnerability. Gnansounou (2008) defined a composite index of energy demand/supply weaknesses as a proxy of energy vulnerability. The index is based on several indicators such as energy intensity, oil and gas import dependency, $\mathrm{CO}_{2}$ content of primary energy supply, electricity supply weaknesses and non-diversity in transport fuels. The assessment of the composite index was applied on selected industrialised countries. In 2008, the World Energy Council (2008) identified threats to the European economy which could lead to potential energy crises and suggested solutions for facing related key challenges. The study also developed a number of indicators to assess the level of different types of vulnerability, as well as the overall vulnerability of a country or region, including threats to physical disruption and higher energy prices.

The design of a composite index of energy security has been undertaken in previous studies. A composite vulnerability index was developed by the World Energy Council (2008) to benchmark and monitor European countries' respective efforts to cope with long-term energy vulnerability. Similarly, de Jong, et. al. (2007) designed state-of-the-art 
indexes of energy security risk (ie., the Crisis Capability Index and Supply/Demand Index) which are oriented towards a comprehensive and analytical representation of the energy supply chain. However, the shortcoming of these approaches was the use of subjective-opinion-dominated weighting systems and scoring rules where the weights and the rules were based on expert judgements. In response to this shortcoming, Gnansounou (2008) proposed an alternative method which was objective-value-oriented and statisticsbased. Gnansounou defined the composite index as the Euclidean distance to the best energy security case represented by the zero point. The Euclidean distance is standardised in order to get a value between 0 and 1 .

\section{Constructing the GSSI for the Asian gas market}

The oil shocks in the 1970 s demonstrated how vulnerable the world's economy was to supply interruptions and price volatility. Any energy infrastructure, oil, coal or natural gas, is often vulnerable to disruption by insufficient supply, accident or malice. Terrorism, technical mishap, or natural disasters that damage the energy system could be nearly as devastating as a sizeable war. Inadequate financial resources also increase vulnerability or insecurity by limiting supply, transmission, and reliability while increasing prices of energy imports adversely affect the macroeconomic balance of payments, contribute inflationary pressures, and displace other consumption and investment because short-term demand is inelastic. In the past, long term contracts between exporters and importers are an important element of security of supply (Czernie, 2002). However, in the last several years long terms contracts are not adequate assurance 
of uninterrupted deliveries. There has been a strong trend towards shorter contract terms or a considerable decrease in the length of natural gas contracts caused by either marketrelated or regulatory-related changes. Market changes due to federal regulatory initiatives and the creation of competitive markets in natural gas and transmission have led to this trend (Petrash, 2006).

In line with the analyses made in previous literature, four distinct security of supply indicators were selected for this study: gas intensity $\left(G_{1}\right)$, net gas import dependency $\left(G_{2}\right)$, ratio of domestic gas production to total domestic gas consumption $\left(G_{3}\right)$ and geopolitical risk $\left(\mathrm{G}_{4}\right) \cdot \mathrm{G}_{1}$ is measured as the ratio of gas consumed in an economy to gross domestic product (GDP). It is the amount of natural gas needed to produce a dollar's worth of goods and services and provides an indication of efficient use of gas to produce the economy's output. $G_{2}$ is expressed as the ratio of net imported gas consumption to total primary energy consumption. $\mathrm{G}_{3}$ is measured as the ratio of domestic gas production to total domestic gas consumption. Domestic production is a better indicator of the country's capacity to cope with short-term supply disruption than domestic reserves as production excludes gas from stranded reserves which cannot be tapped immediately. $\mathrm{G}_{4}$ represents the exposure of an economy to political risk and is measured on the basis of two factors: diversification of gas import sources and political stability in gas-exporting countries. The details of the method of calculation of these indicators are provided in the Appendix. Appendix Table 1 presents estimates of the four security of supply indicators of seven net gas importing countries in Asia. 
High gas intensity of GDP results in larger adjustments costs and impacts on gas supply security in the event of natural gas supply shocks. In addition, the higher the share of imported gas in total energy demand the more vulnerable an economy is to international gas developments. Diversification of supply sources, particularly politically stable supply sources also reduces the risk and vulnerability to disruption. Dependence on domestically-sourced gas supply is preferred over imported gas, as it avoids geopolitical uncertainties. In addition, the larger domestic gas reserves relative to consumption or the larger domestic production capabilities a country has, the lesser are the likely impacts on gas security.

It is difficult to quantify a country's overall gas supply security using individual indicators and it is even more difficult to synthesise different indicators. To facilitate comparison or aggregation of several indicators, it may be better for these to be expressed in the same units. To do this, for each of the four security indicators, a relative indicator $\varphi_{i}$, was estimated which was used to compute a composite index — gas supply security index (GSSI). The relative indicators were estimated by using a scaling technique where the minimum value is set to 0 and the maximum to 1 . The value of 0 is assigned to the country with the least vulnerability or insecurity to supply disruptions and the value 1 is assigned to the country with the most vulnerability to supply shocks. Table 1 presents calculations for the relative indicators which are scaled values of the four security of supply indicators. 
Table 1. Relative indicators of security of supply in selected net gas importing countries in Asia, 2008 (arranged in ascending order of vulnerability/insecurity)

\begin{tabular}{llllllll}
\hline & \multicolumn{3}{c}{$\varphi_{1}$} & \multicolumn{3}{c}{$\varphi_{3}$} & \multicolumn{3}{c}{$\varphi_{4}$} \\
\hline China & 0.000 & China & 0.000 & China & 0.000 & Japan & 0.000 \\
Japan & 0.008 & India & 0.126 & Thailand & 0.181 & Korea & 0.200 \\
Taiwan & 0.126 & Thailand & 0.533 & India & 0.213 & India & 0.535 \\
India & 0.134 & Taiwan & 0.589 & Japan & 0.970 & Taiwan & 0.626 \\
Korea & 0.202 & Korea & 0.836 & Korea & 1.000 & China & 0.788 \\
Singapore & 0.277 & Singapore & 0.780 & Singapore & 1.000 & Singapore & 0.848 \\
Thailand & 1.000 & Japan & 1.000 & Taiwan & 1.000 & Thailand & 1.000 \\
AVERAGE & 0.249 & AVERAGE & 0.552 & AVERAGE & 0.628 & AVERAGE & 0.571 \\
\hline
\end{tabular}

Source: Author's calculations

Note: $\varphi_{1}$ is the relative indicator or scaled value for $\mathrm{G}_{1}$ (gas intensity); $\varphi_{2}$ is the relative indicator or scaled value for $\mathrm{G}_{2}$ (net gas import dependency); $\varphi_{3}$ is the relative indicator or scaled value for $\mathrm{G}_{3}$ (ratio of domestic gas production to total domestic gas consumption); $\varphi_{4}$ is the relative indicator or scaled value for $\mathrm{G}_{4}$ (geopolitical risk).

Following Gnansounou (2008), the gas supply security index (GSSI) is derived as the root mean square of the four relative indicators or scaled values of the four security of supply indicators.

$$
G_{S S I} \ldots=\cdots \sqrt{\frac{\sum_{i=1}^{4} \varphi_{i j}^{2}}{4}}
$$

The various relative indicators of gas security are interrelated and that the GSSI derived provides a composite quantitative measure of gas security by taking into account the interactions and interdependence between the identified set of indicators. The GSSI captures the sensitivity of the Asian economies to developments in the international gas market, with a higher index indicating higher gas supply insecurity or vulnerability. 


\section{Empirical results}

In this paper, the GSSI was estimated for seven Asian net gas-importing economies of Japan, Korea, Taiwan, China, India, Singapore and Thailand for 2008. The final values of GSSI for our sample net gas-importing countries in Asia are shown in Figure 1.

Figure 1. Gas security of supply index of selected net gas-importing countries in Asia (2008)

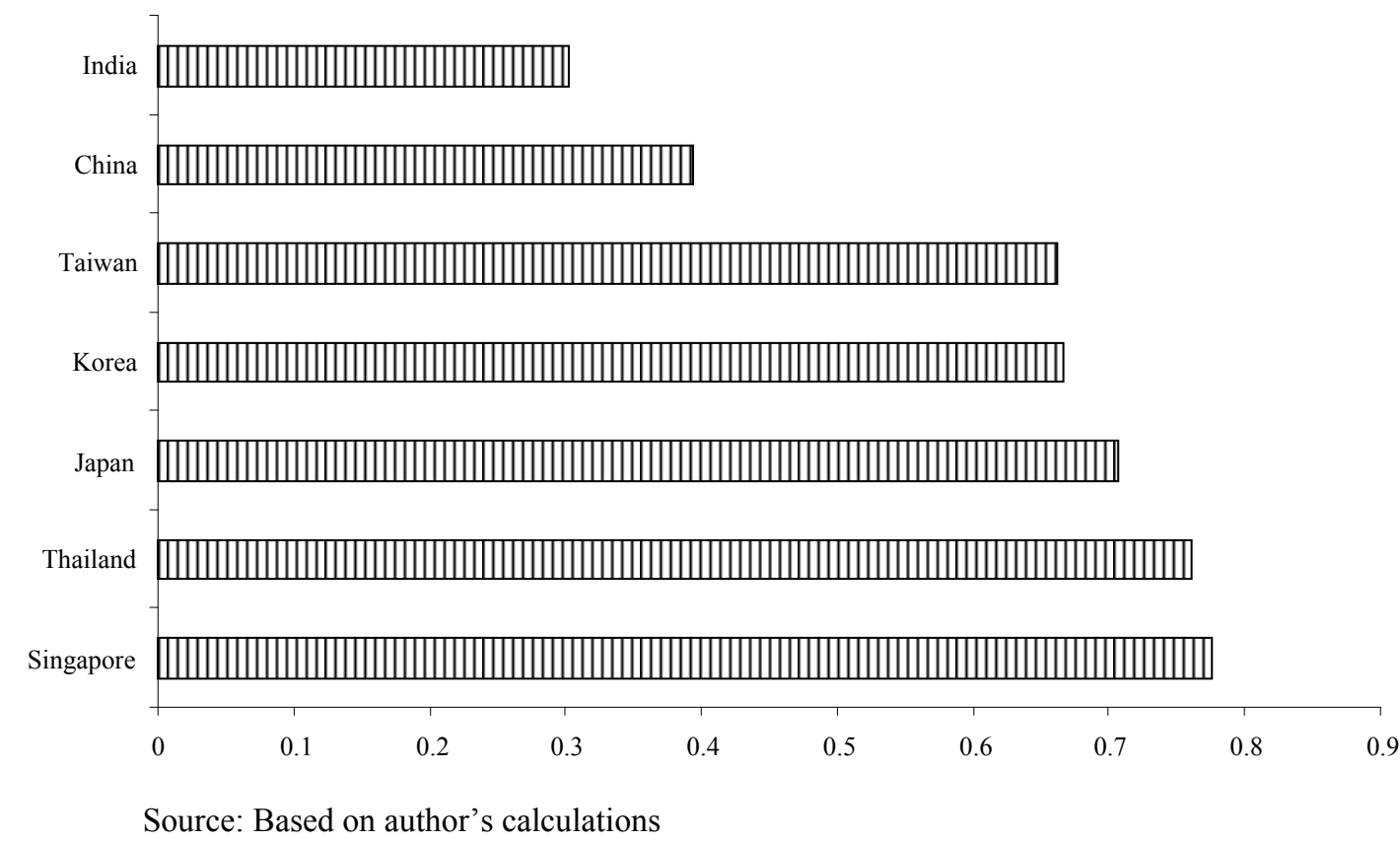

In our sample, India is least vulnerable in the event of a natural gas supply disruption. It registered the lowest GSSI at 0.302 . The strength of this country is on $\mathrm{G}_{2}$ indicating a relatively low gas import dependency, and to a less extent on $\mathrm{G}_{1}$ for having low gas intensity. In India, natural gas is a minor fuel in the overall energy mix representing only 8.6 per cent of total primary energy consumption in 2008. In that same year, India's 
natural gas imports represent just over 2 per cent of its energy mix and hence not reliant on imports. With coal as the major source of energy for power generation, gas intensity of the economy's GDP is low. However, India's consumption of natural gas has risen faster than any other fuel. The power and fertiliser industries are the key demand drivers for natural gas. With domestic gas production only large enough to satisfy almost threequarters of its domestic gas consumption, India's domestic natural gas supply is not likely to keep pace with demand. Despite major new natural gas discoveries in recent years, the country will have to import more, either via pipeline or as LNG. With an increase in the demand and supply for natural gas and with multiple new players entering the market, the Indian government's Petroleum and Natural Gas Regulatory Board Act of 2006 has promoted competition among market players and stabilised natural gas supply (Thacker, 2006).

The bulk of India's natural gas production comes from the western offshore regions, especially the Mumbai High basin. The onshore fields in Assam, Andhra Pradesh, and Gujarat states are also major producers of natural gas. In 2008, around 26 per cent of supply came from imported LNG. Currently, there are two regasification terminals located on the Western coast of India, Dahej and Hazira. The Dahej terminal is being supplied from Qatar under a long term contract, supplemented by spot cargoes from other sources. A possible source of supply for Hazira terminal is Australia's Gorgon LNG project. By 2010, India intends to have two more import terminals, Dabhol - Ratnagiri and Kochi. A contractual agreement on the pricing formula for gas has been signed and plans to import gas through the Iran-Pakistan-India pipeline have progressed. Other 
possible sources of imported gas are Bangladesh and Myanmar. The natural gas reserves of Bangladesh could be linked into the Indian gas grid while new natural gas find in Myanmar could be supplied via pipeline running across Bangladeshi territory to West Bengal in India provided agreement could be reached among parties concerned (EIA, 2008).

China ranked $2^{\text {nd }}$ as less gas-vulnerable country in the sample. China's major strengths are on $\mathrm{G}_{1}, \mathrm{G}_{2}$ and $\mathrm{G}_{3}$. Its only weakness is on $\mathrm{G}_{4}$. China is rich in energy resources, particularly coal. Natural gas consumption in China is significantly less than other fossil fuels. Natural gas generally occupies a very small share (3.6 per cent in 2008) in China's energy mix and use of domestic gas production is limited to areas near production sites such as in Sichuan, Liaoning and Heilongjiang Provinces, where low cost gas is possible. Despite an almost 10 per cent increase in domestic production of natural gas in 2008 , coal and oil resources were utilised more extensively than natural gas for power generation and industrial development purposes. Natural gas is primarily used as a feed stock for chemical fertiliser and to operate oil and gas fields. China's major gas fields are located in the western part of the country, making transport to eastern demand centres difficult. Gas use in China is still small but is expected to double by 2030 (Komiyama, et.al., 2005; APERC, 2008). This growth will be driven mainly by the increased use of gas for power generation and increased residential consumption in urban areas. While some of the rising demand will be fulfilled through increases in domestic production, a large portion will come from pipeline and LNG imports. Due to geographical accessibility, the small amount of imported LNG goes to southern provinces along the coast like Guangdong and 
Fujian. The International Energy Agency (2002) notes that obstacles to the development of China's natural gas industry include small and distant proven reserves, lack of gas transport infrastructure, high cost relative to alternative fuels, and lack of coherent government policy towards the industry.

In 2008, China had six import sources compared to one import source in 2006. However, most of the additional import sources are politically unstable which explains China's relative poor performance on $\mathrm{G}_{4}$. China received its first-ever LNG cargo in mid-2006 under a long-term contract with Australia. Australia remains China's major source of LNG. Its second terminal in Fujian started receiving cargoes from Indonesia in 2008. Another regasification terminal in the Shanghai area started to import LNG from Malaysia in 2009. In the northern inland areas of China, natural gas supply is likely to come from Siberia, Turkmenistan, Sakhalin and Sakha.

Of the seven sample countries, Taiwan ranked $3^{\text {rd }}$ with a GSSI of 0.662 . Its major weakness is on $\mathrm{G}_{3}$ due to a very limited amount of domestic gas production and indeed has very limited domestic energy resources. As Taiwan lacks sufficient domestic energy sources, it is almost totally dependent on energy imports. There is no coal and oil reserves and natural gas resources are limited at around 0.4 billion cubic metres in 2008 . Its strength on $\mathrm{G}_{1}$ as having low gas intensity is because oil is by far the dominant fuel in Taiwan's energy mix. In 2008, Taiwan had to import around 96 per cent of its energy requirements. Domestic demand for natural gas was met almost entirely by LNG imports which grew by almost 10 per cent in 2008 , more than 50 per cent of which come from 
Indonesia and Malaysia. Taiwan also receives small amounts of LNG imports from Trinidad and Tobago, Nigeria, Oman, Qatar, Algeria, Egypt and Equatorial Guinea. To facilitate supply and expand the use of natural gas, Taiwan has completed transmission and distribution network along the country's west coast, which includes main trunk pipeline and regional distribution stations. To diversify its LNG supply, Taiwan has signed a 25-year LNG purchase agreement with RasGas of Qatar and has been constructing a new LNG import terminal in Taichung to expand import capacity (IEA, 2007; EIA, 2007b).

Coming closely on $4^{\text {th }}$ rank is Korea with $\mathrm{G}_{4}$ and $\mathrm{G}_{1}$ as its major strengths. To reduce the economy's dependence on imported oil, Korea introduced LNG in the 1980s to power its natural gas-based city gas to the residential sector. Since then, natural gas use has grown rapidly. Korea relies on imported LNG for most of its natural gas, though it began producing a small quantity of natural gas from one offshore field in 2004. Korea is the second largest importer of LNG worldwide accounting for 16 per cent of total LNG imports in 2008. The bulk of Korea's LNG imports come from a much diversified group of sources which explains its strength on $\mathrm{G}_{4}$. These import sources include Qatar, Indonesia, Malaysia, and Oman, with smaller volumes coming from Trinidad and Tobago, Algeria, Nigeria, Belgium, Egypt, Brunei Darussalam and Australia, and occasional spot cargoes from elsewhere. Korean natural gas demand is shared almost evenly between the electricity sector and the residential heating sector, with a smaller amount consumed in petrochemical plants. With demand growing at an average annual growth rate of 48 per cent between 2003 and 2008, Korea continues to sign contracts for 
additional supplies, though most of the new LNG term contracts in the past few years have included more flexibility for the purchaser in terms of the ability to lower volumes if necessary. To ensure stable supply for gas, Korea is also increasing LNG storage capacity at its existing terminals (EIA, 2007a).

Japan ranked $5^{\text {th }}$ in terms of gas supply vulnerability in the event of a supply disruption. It registered a GSSI of 0.707 . Japan's security of supply profile is relatively weak on $\mathrm{G}_{2}$ which is a measure of net import dependency, and $\mathrm{G}_{3}$ which is the ratio of domestic production to domestic consumption of natural gas. Like Korea, Japan does not have significant domestic natural gas reserves and production, and gas is imported in the form of LNG. Of the total primary energy consumption in 2008, approximately 16 per cent is imported natural gas. Japan's demand for natural gas has been increasing rapidly at an average annual growth rate of 4.3 per cent between 1980 and 2008. This is due mainly to the revision of the Gas Utility Industry Law where there has been increased competition in the industry as market entry and prices have been deregulated. In 2008, Japan imported 98 per cent of its gas requirements and domestic demand was met almost entirely by LNG. LNG imports into Japan comprised 41 per cent of total world LNG trade, which mostly come from Indonesia, Malaysia, Brunei Darussalam, Australia and Qatar. Natural gas is mainly used for electricity generation, reticulated city gas and industrial fuels. Since Japan has placed priority on the stable and secure supply of LNG, Japanese LNG buyers have been in general paying a higher price than buyers in Europe or the United States under the long-term take or pay contracts with rigid terms on volume and price. Japan lacks a national pipeline network which could interconnect its consuming areas. 
The possibility of a significant disruption at one LNG terminal in Japan poses a potential supply vulnerability issue.

Despite its strength on $\mathrm{G}_{3}$, Thailand is the second most vulnerable country in our sample in the event of a supply shock. Thailand is endowed with production and reserves of natural gas, about 94 per cent of which is found in the Gulf of Thailand. Supply sources of natural gas are both from domestic fields and piped imports from Myanmar, though LNG remains a long-term option for Thailand. Imports of LNG have been confirmed with the planned construction of a receiving terminal on the east coast of the country by 2011, with supply coming from Iran. Additional supply of natural gas is also expected from the Malaysia - Thailand Joint Development Area (JDA) (EIA, 2007c). Thailand's relative weakness in $\mathrm{G}_{4}$ is due to having only one source of imports with a very low political stability rating. Its economy's high gas dependence in power generation is evident in its relative weakness in $G_{1}$ which makes it vulnerable to supply shocks. Thailand uses 74 per cent of its natural gas supply for power generation and 70 per cent of its power comes from gas-based technology (Nakawiro and Bhattacharyya, 2007). Thailand's high gas intensity is facilitated by a relatively well-established natural gas regulatory framework where third party access in gas transmission is quite developed and meant the existence non-discriminatory access to the gas transmission system based on tariffs reflecting costs that provide a fair and reasonable rate of return (Chandler and Padungkittimal, 2008). 
Singapore is the most vulnerable country in our sample with a GSSI of 0.775 . Singapore's gas security of supply profile is relatively weak on $\mathrm{G}_{2}$ and $\mathrm{G}_{4}$ but more so on $\mathrm{G}_{3}$. The absence of domestic gas production combined with high domestic gas consumption makes Singapore relatively vulnerable to natural gas supply disruptions. Its consumption has risen rapidly in recent years owing mostly to government programs aimed at reducing carbon dioxide and sulphur emissions and encouraged the use of natural gas for power generation and petrochemical production (EIA, 2007d). In 2008, natural gas accounted for almost 15 per cent of Singapore's total primary energy demand. Singapore relies entirely on imports to meet its natural gas requirements which are mainly used for power generation and petrochemical production. Around three quarters of Singapore's fuel demand for electricity production come from natural gas. With gas representing such a large share of electricity production, diversification of supply is an important issue. Currently, all of Singapore's piped natural gas imports come from Malaysia and Indonesia. However, the Energy Market Authority of Singapore is currently studying the viability of building an LNG import terminal, thereby freeing itself from dependence on neighbouring states for its natural gas supply. An agreement was also signed to supply LNG to the import terminal on Singapore's Jurong Island by 2012.

Sensitivity of the GSSI to changes in values of the indicators. The analysis presented earlier highlights the sensitivity of the GSSI to the parameter values used. In particular, it is important in the evaluation of the GSSI to examine its sensitivity to changes in the values of the relative indicators of security of supply $\left(\varphi_{i}\right.$ 's) which in turn are based on the values of the $\mathrm{G}_{\mathrm{i}}$ 's. Using 2006 data to calculate the values for $\mathrm{G}_{1}, \mathrm{G}_{2}, \mathrm{G}_{3}$ and $\mathrm{G}_{4}$ for the 
same group of countries, it is interesting to note that there were no significant differences in the estimated values of the relative indicators (Table 2) and values of GSSIs to drastically change the relative vulnerability ranking of countries (Table 3 ). The constant relative ranking was not surprising despite strong growth trends in production, consumption and imports of natural gas from 2006 to 2008, particularly by China and India. As this growth trend generally occurred across all the Asian countries, its impact on the values of the relative indicators was minimal as it scaled the values in the same direction.

Table 2. The relative indicators of security of supply in selected net gas importing countries in Asia, 2006 (arranged in ascending order of vulnerability/insecurity)

\begin{tabular}{llllllll}
\hline & \multicolumn{3}{c}{$\varphi_{1}$} & & & & \multicolumn{2}{c}{$\varphi_{3}$} & & $\varphi_{4}$ \\
\hline Japan & 0.000 & China & 0.000 & China & 0.000 & Japan & 0.000 \\
China & 0.016 & India & 0.117 & India & 0.149 & Korea & 0.202 \\
Taiwan & 0.109 & Taiwan & 0.569 & Thailand & 0.245 & Taiwan & 0.646 \\
Korea & 0.155 & Thailand & 0.662 & Taiwan & 0.840 & India & 0.734 \\
India & 0.202 & Singapore & 0.840 & Japan & 0.968 & Singapore & $0 . .796$ \\
Singapore & 0.240 & Korea & 0.961 & Korea & 1.000 & China & 1.000 \\
Thailand & 1.000 & Japan & 1.000 & Singapore & 1.000 & Thailand & 1.000 \\
AVERAGE & 0.215 & AVERAGE & 0.519 & AVERAGE & 0.525 & AVERAGE & 0.571 \\
\hline \multicolumn{2}{l}{ Source: Based on author's calculations } & & & & &
\end{tabular}

Table 3. Gas security of supply index of selected net gas-importing countries in Asia, 2006 and 2008 (arranged in ascending order of overall vulnerability/insecurity)

\begin{tabular}{ll|ll}
\hline \multicolumn{2}{c|}{2006} & & \multicolumn{2}{l}{2008} & \\
\hline India & 0.385 & India & 0.302 \\
China & 0.500 & China & 0.394 \\
Taiwan & 0.607 & Taiwan & 0.662 \\
Thailand & 0.666 & Korea & 0.667 \\
Japan & 0.697 & Japan & 0.707 \\
Korea & 0.701 & Thailand & 0.761 \\
Singapore & 0.768 & Singapore & 0.775 \\
\hline
\end{tabular}

Source: Based on author's calculations 
An examination of the GSSIs for 2006 and 2008 of individual countries reveal noteworthy observations. Of the seven countries in the sample, only China and India experience a decline in their GSSIs from 2006 to 2008. This indicates a distinct improvement in the security of natural gas supply in China and India brought about by lower gas intensities, higher production and more diversified import sources. All the other Asian countries in the sample became more vulnerable in 2008 with their GSSIs rising as a consequence of higher gas intensities and higher consumption relative to production.

\section{Conclusion}

Many factors determine gas vulnerability of an economy. Domestic production, gas efficiency usage, volume and sources of gas imports are very crucial in determining an economy's vulnerability. The analysis in this paper highlights inter-country differences in individual and overall indicators of gas security which means that country differences exist with respect to vulnerability to natural gas supply disruptions. This implies that governments need to develop policy responses that directly address individual countries' weaknesses to enable them to handle natural gas supply disruptions. Policy measures should reduce the probability of supply disruptions occurring and the costs of disruptions. For instance, India and China are relatively less vulnerable to supply disruptions compared to other countries in the sample because of their significant domestic gas 
production and small share of gas in its energy mix. These meant that the two countries did not have to rely on gas imports for energy generation.

Governments could implement various measures to better cope with supply disruptions and significantly mitigate their effects. For instance, gas import dependence has risks associated with price volatility, natural disaster, political blackmail and terrorism. Imported gas supplies are either pipeline bound or sea bound LNG. These transit options are both exposed to risks but it is the degree of having viable alternative options that defines security of supply. When gas imports depend dangerously on too few sources, it raises a concern whether this is compatible with a sensible policy goal of gas supply security. This concern is exacerbated when taking geopolitical considerations into account. Hence, diversification of gas import sources is encouraged. Other diversification measures include fuel-switching and diversifying energy mix. Diversification in fuel types and sources would reduce the costs of supply disruptions by spreading the risks across different import and energy sources. As Percebois (2006) and Reymond (2007) summed it, a country which imports the majority of its gas at a sustainable cost and ensures the security of supply by well-diversified and politically-stable sources will not be vulnerable.

Governments also have the option of reducing overall gas dependence by improving gas efficiency through research and development and adoption of technologies that reduce gas consumption or increase the efficiency of gas use, technologies that facilitate gas exploration and production, and alternative processing technologies such as gas to liquids 
plant. To enhance natural gas supply security, it is also important that investments in domestic gas exploration and production activities are encouraged though joint venture projects and that gas trade routes and sea lanes remain open and secure.

\section{References}

Asia-Pacific Economic Cooperation (APEC) Secretariat, 2006, Potential for Growth of Natural Gas as a Clean Energy Source in APEC Developing Economies, APEC Energy Working Group on Clean Fossil Energy, Singapore.

APERC (Asia Pacific Energy Research Centre), 2008, APEC Energy Overview 2007, The Institute of Energy Economics, Japan.

, 2007, A Quest for Energy Security in the 21 ${ }^{\text {st }}$ Century: Resources and Constraints, Institute of Energy Economics, Japan.

British Petroleum (BP), 2009, BP Statistical Review of World Energy, June (http://www.bp.com/statisticalreview).

Cabalu, H. and Manhutu, C., 2009, Vulnerability of natural gas supply in the Asian gas market, Economic Analysis and Policy, Vol. 39, No. 2. 
Chandler, A. and Padungkittimal, N., 2008, Thai Power Sector, July (downloaded from http://www.ctlo.com/TPS-2.htm on 19 August 2009).

Costantini, V., Gracceva, F., Markandya, A. and Vicini, G., 2007, Security of energy supply: comparing scenarios from a European perspective, Energy Policy, Vol. 35, pp. 210-226.

Czernie, W., 2002, 'Security of gas supply and long-term contracts,' Presentation to the IEA Regulatory Forum on Competition in Energy Markets: Implications for Public Service and Security of Supply Goals in the Electricity and Gas Industries, Paris.

de Jong, J., Maters, H., Scheepers, M. and Seebregts, A., 2007, EU Standards for Energy Security of Supply: Updates on the Crisis Capability Index and the Supply/Demand Index Quantification for EU-27, Energy Research Centre of the Netherlands and Clingendael International Energy Programme.

Dolader, J., 2003, Gas Security of Supply in a Liberalised Market, June, Paris.

ECN (Energy Research Centre of the Netherlands), 2004, Designing Indicators of Longterm Energy Supply Security. 
Energy Information Administration (EIA), 2008, Energy Profile of India, in Encyclopedia of Earth, (http://www.eoearth.org/article/Energy profile_of_India).

, 2007a, Energy Profile of South Korea, in Encyclopedia of Earth, (http://www.eoearth.org/article/Energy_Profile_of_South_Korea).

, 2007b, Energy Profile of Taiwan, in Encyclopedia of Earth, ((http://www.eoearth.org/article/Energy_Profile_of_Taiwan).

, 2007c, Energy Profile of Thailand, in Encyclopedia of Earth, ((http://www.eoearth.org/article/Energy_Profile_of_Thailand).

, 2007d, Energy Profile of Singapore, in Encyclopedia of Earth, (http://www.eoearth.org/article/Energy_Profile_of_Singapore).

, 2005, International Energy Outlook, U.S. Department of Energy, p. 37, (http://www.eia.doe.gov/oiaf/ieo/nat_gas.html).

Gnansounou, E., 2008, 'Assessing the energy vulnerability: case of industrialised countries,' Energy Policy, Vol. 36, pp. 3734-3744.

Gupta, E., 2008. 'Oil vulnerability index of oil-importing countries,' Energy Policy, Vol. 36, pp. 1195-1211. 
International Association for Energy Economics (IAEE), 2007, 'Natural gas: is there a decreasing trend?' IAEE Newsletter, Vol. 16, Third Quarter 2007.

International Energy Agency (IEA), 2007, Natural Gas Market Review 2007: Security in a Globalising Market to 2015, OECD, Paris. , 2002, Developing China’s Natural Gas Market: The Energy Policy Challenges, OECD, Paris.

International Monetary Fund (IMF), 2009, World Economic Outlook Database downloaded from http://www.imf.org/external/pubs/ft/weo/2009/01/ weodata/index.aspx.

Jansen, J., van Arkel, W. and Boots, M., 2004, Designing Indicators of Long-term Energy Supply Security, ECN-C-04-007, January 2004, The Energy research Centre of Netherlands.

Kendell, J., 1998, Measures of Oil Import Dependence, Energy Information Administration, U.S. Department of Energy (downloaded from http:/www.eia.doe.gov/oiaf/archive/issues98/oimport.html, on 16 February 2009). 
Komiyama, R., Zhidong, L. and Ito, K., 2005, 'World energy outlook in 2020 focusing on China's energy impacts on the world and Northeast Asia', International Journal of Global Energy Issues, Vol. 24, No. 3-4, pp. 183-210.

Nakawiro, T. and Bhattacharyya, S., 2007, 'High gas dependence for power generation in Thailand: the vulnerability analysis,' Energy Policy, Vol. 35, Issue No. 6, pp. 33353346.

Percebois, J., 2006, Dépendance et vulnérabilité: deux façons connexes mais différentes d'aborder les risques énergétiques. Cahiers de recherché CREDEN, No. 06.03.64, $17 \mathrm{pp}$.

Percebois, J., 2007, 'Energy vulnerability and its management,' International Journal of Energy Sector Management, Vol. 1, No. 1, pp. 51-62.

Petrash, J., 2006, 'Long-term natural gas contracts: dead, dying or merely resting?' Energy Law Journal, Vol 27, No. 2, pp. 545-582.

Reymond, M., 2007, 'European key issues concerning natural gas: dependence and vulnerability,' Energy Policy, Vol. 35, pp. 4169-4176.

Thacker, S., 2006, 'Recent Indian Petroleum, Petroleum Products and Natural Gas Regulations,' Hydrocarbon World, December, pp. 23-24. 
United Nations Development Programme (UNDP), 2007, Overcoming Vulnerability to Rising Oil Prices: Options for Asia and the Pacific, UNDP Regional Centre, Bangkok.

World Bank, 2009, Worldwide Governance Indicators1996-2008 downloaded from http://info.worldbank.org/governance/wgi/index.asp.

World Energy Council, 2008, Europe’s Vulnerability to Energy Crises, London, United Kingdom.

\section{Acknowledgements}

This paper is partly based on a conference paper 'Vulnerability of Natural Gas Supply in the Asian Gas Market' presented at the $37^{\text {th }}$ Australian Conference of Economists in Queensland, Australia. The author thanks Ms Chassty Manuhutu for her valuable contribution to an early version of this paper. 


\section{Appendix}

Gas intensity $\left(G_{1}\right)$

$$
G_{1 j} \ldots=\cdots \frac{G C_{j}}{G D P_{j}}
$$

The gas intensity of GDP of country $j\left(G_{1 j}\right)$ is measured as the ratio of total natural gas consumed in country $j\left(G C_{j}\right)$ to GDP of country $j\left(G D P_{j}\right)$ and expressed as cubic meter per unit of GDP or $\mathrm{m}^{3} /$ GDP. The country's output of goods and services is measured by inflation-adjusted GDP.

The relative indicator for country $j$ associated with $G_{1}\left(\varphi_{1 j}\right)$ is estimated as:

$$
\varphi_{1 j}=\frac{G_{1 j}-\operatorname{Min}\left(G_{1}\right)}{\operatorname{Max}\left(G_{1}\right)-\operatorname{Min}\left(G_{1}\right)}
$$

The relative indicator, $\varphi_{1 j}$ results in projection of $G_{1 j}$ in the interval $[0,1]$. A low value of $\varphi_{1 j}$ means that country $j$ is less vulnerable or less insecure to supply shocks compared to other countries in the study.

Net gas import dependency $\left(G_{2}\right)$

$$
G_{2 j \ldots}=\ldots \frac{G M_{j}}{T_{P E C}}
$$


The gas import dependency of country $j\left(G_{2 j}\right)$ is expressed as the ratio of net imports of natural gas in country $j\left(G M_{j}\right)$ to total primary energy consumption in country $j$ $\left(T P E C_{j}\right)$. Its unit is in percentage.

Similarly, the relative indicator for country $j$ associated with $G_{2}\left(\varphi_{2 j}\right)$ is estimated as:

$$
\varphi_{2 j}=\frac{G_{2 j}-\operatorname{Min}\left(G_{2}\right)}{\operatorname{Max}\left(G_{2}\right)-\operatorname{Min}\left(G_{2}\right)} .
$$

The above adjustment transforms the indicator in the $[0,1]$ interval with the value of 0 being assigned to the country with the lowest value of the selected security of supply indicator and least vulnerable and the value 1 is assigned to the country with the highest value of the selected indicator and hence most vulnerable.

Ratio of domestic gas production to total domestic gas consumption $\left(G_{3}\right)$

$$
G_{3 j} \cdots=\cdots \frac{G P_{j}}{G C_{j}}
$$

where $G P_{j}$ is domestic natural gas production in country $j$ and $G C_{j}$ is total natural gas consumed in country $j$.

This indicator, unlike the first two, is negatively related to gas supply vulnerability or security. A high value for $\mathrm{G}_{3}$ means that country $j$ is less vulnerable or less insecure to 
supply shocks compared to other countries in the study. To accommodate this negative relationship, the relative indicator for country $j$ associated with $G_{3}\left(\varphi_{3 j}\right)$ is estimated as:

$$
\varphi_{3 j}=\frac{\operatorname{Max}\left(G_{3}\right)-G_{3 j}}{\operatorname{Max}\left(G_{3}\right)-\operatorname{Min}\left(G_{3}\right)} .
$$

The above adjustment transforms the indicator in the $[0,1]$ interval with the value of 0 being assigned to the country with the highest value of the selected security of supply indicator and least vulnerable and the value 1 is assigned to the country with the lowest value of the selected indicator and hence most vulnerable.

\section{Geopolitical risk $\left(G_{4}\right)$}

This is largely determined by the degree of diversification of gas import sources and the associated political stability of these sources. ECN (2004) has suggested a methodology for quantifying such risk using the adjusted Shannon diversity index. The following formula describes such index.

$$
S=-\sum_{i}\left(h_{i} m_{i} \ln m_{i}\right)
$$

where:

$S=$ Shannon index of import flows of gas, adjusted for political stability in exporting country $i$

$h_{i}=$ extent of political stability in exporting country $i$, ranging from 0 (extremely unstable) and 1 (extremely stable); and $m_{i}=$ share of gas imports from country $i$ in total gas imports. 
The relative indicator for country $j$ associated with $G_{4}\left(\varphi_{4 j}\right)$ is estimated as:

$$
\varphi_{4 j}=\frac{\operatorname{Max}\left(G_{4}\right)-G_{4 j}}{\operatorname{Max}\left(G_{4}\right)-\operatorname{Min}\left(G_{4}\right)}
$$

Like $\varphi_{3 j}$, this indicator is negatively related to gas supply vulnerability or security which means that a lower value for $\mathrm{G}_{4}$ suggests high vulnerability to supply shocks or a worse gas supply situation (i.e., high insecurity). The above adjustment transforms the indicator in the $[0,1]$ interval with the value of 0 being assigned to the country with the highest value of the selected security of supply indicator and least vulnerable and the value 1 is assigned to the country with the lowest value of the selected indicator and hence most vulnerable.

Appendix Table 1. Individual gas security of supply indicators for seven net-importing countries in Asia, 2008 (arranged in ascending order of vulnerability/insecurity)

\begin{tabular}{cc|cc}
\hline $\mathrm{G}_{1}\left(\mathrm{~m}^{3} / \$\right)$ & $\mathrm{G}_{2}(\%)$ & $\mathrm{G}_{3}(\%)$ & $\mathrm{G}_{4}$ \\
\hline China & China & China & Japan \\
$(0.018)$ & $(0.20)$ & $(94)$ & $(1.247)$ \\
Japan & India & Thailand & Korea \\
$(0.019)$ & $(2.24)$ & $(77)$ & $(0.998)$ \\
Taiwan & Thailand & India & India \\
$(0.033)$ & $(8.81)$ & $(74)$ & $(0.580)$ \\
India & Taiwan & Taiwan & Taiwan \\
$(0.034)$ & $(9.70)$ & $(0)$ & $(0.467)$ \\
Korea & Singapore & Japan & China \\
$(0.042)$ & $(12.79)$ & $(0)$ & $(0.264)$ \\
Singapore & Korea & Korea & Singapore \\
$(0.051)$ & $(13.70)$ & $(0)$ & $(0.190)$ \\
Thailand & Japan & Singapore & Thailand \\
$(0.137)$ & $(16.34)$ & $(0)$ & $(0.0)$ \\
Average & Average & Average & Average \\
$(0.048)$ & $(9.11)$ & $(35)$ & $(0.535)$ \\
\hline
\end{tabular}

Source: Author's computations

Note: $\mathrm{G}_{1}=$ Gas intensity; $\mathrm{G}_{2}=$ Net gas import dependency; $\mathrm{G}_{3}=$ ratio of domestic gas production to total domestic gas consumption; $\mathrm{G}_{4}=$ geopolitical risk; 
The data on GDP in 2008 were taken from World Economic Outlook Database (IMF, 2009). Data for natural gas - domestic production, domestic consumption and trade movements in volume terms were taken from BP Statistical Review of World Energy (2009). In this study, the percentile rank of an exporting country in the World Bank's Worldwide Governance Indicators for political stability in 2008 was used to determine $h_{i}$ (Appendix Table 2).

Appendix Table 2. Political risk rating of selected gas-producing countries (2008)

\begin{tabular}{|c|c|}
\hline Country & Political Stability \\
\hline Algeria & 13.3 \\
\hline Australia & 85.1 \\
\hline Belgium & 69.0 \\
\hline Brunei & 93.3 \\
\hline China & 33.4 \\
\hline Egypt & 22.9 \\
\hline Equatorial Guinea & 40.0 \\
\hline India & 16.7 \\
\hline Indonesia & 15.7 \\
\hline Japan & 79.4 \\
\hline Korea & 59.8 \\
\hline Malaysia & 50.2 \\
\hline Myanmar & 9.0 \\
\hline Nigeria & 3.3 \\
\hline Norway & 97.0 \\
\hline Oman & 79.9 \\
\hline Qatar & 83.2 \\
\hline Singapore & 96.1 \\
\hline Taiwan & 71.7 \\
\hline Thailand & 12.9 \\
\hline Trinidad \& Tobago & 47.8 \\
\hline United Arab Emirates & 72.7 \\
\hline United States & 68.4 \\
\hline
\end{tabular}

Source: World Bank, 2009, Worldwide Governance Indicators 1996-2008, downloaded from http://info.worldbank.org/governance/wgi/index.asp and

http://info.worldbank.org/governance/wgi/pdf/wgidataset.xls; Political risk ratings range from 0 for high risk to 100 for low risk. 